\title{
1. An agonistic pluralism approach to the European public sphere
}

\section{Hakan G. Sicakkan}

The 'Eurosphere' is of crucial importance if we want to properly understand what the European public sphere is. For without the Eurosphere, a European public sphere might not emerge. The term 'Eurosphere' was invented by Jacques-René Rabier and Jean Meynaud (Meynaud and Sidjanski 1965: 25). They defined it as the sphere of those who contribute to the European integration processes, those who are directly subjected to its consequences, and those who further the integration process by expressing solidarity with the idea of a united Europe. In other words, the Eurosphere was the vertical, top-down, trans-European communicative space of European-minded, pro-EU and pro-diversity elites and citizens.

In this chapter, I posit the constitutive role of the Eurosphere in the ongoing formation of a European public sphere. In the first section, I extend Rabier and Meynaud's definition of the Eurosphere in terms of its relationship to the European public sphere. I proceed in the same section by presenting a brief history of the making of the Eurosphere by the founding fathers of the European Union. In the second section, by linking the two terms causally in an agonistic pluralist perspective I argue that the Eurosphere has a constitutive role in the formation of the European public sphere. An agonistic pluralist approach to the public sphere requires due attention to, and recognition of, both the adversarial and the harmonious features of politics and society and strives to abandon imperfect assumptions that entail only consensus or dissension. In section three I identify the social spaces, institutions, structures and political actors (adversaries) that constitute the agonistic European public sphere. I conclude by suggesting an analytical framework which is based on an extended agonistic pluralist notion of a European public sphere. 


\section{WHAT IS THE EUROSPHERE?}

The term 'Eurosphere' is often used by Mark Leonard and others to connote the EU's zone of influence in the international political arena:

[T]he next wave of European transformation is only just beginning. The European Union is starting to develop an enormous sphere of influence, extending way beyond its borders that could be called the 'Eurosphere'. This belt of eighty countries covering the former Soviet Union, the Western Balkans, the Middle East, North Africa, and Sub-Saharan Africa accounts for 20 per cent of the world's population. (Leonard 2005: 4)

Indeed, as I underlined, the term 'Eurosphere' was introduced by Jacques-René Rabier and Jean Meynaud in 1965, and their usage of the term refers to quite another thing:

Selon une expression suggérée par J.-R. Rabier et J. Meynaud et qui maintenant est devenue courante, l'eurosphère désigne les diverses sphères de personnes ou de groupes qui participent activement à l'intégration ou qui étant directement touchés par ses effets réagissent d'une manière significative. Ces individus ou groupes manifestent donc des solidarités européennes en influant sur le movement d'intégration ou en s'en défendant. (Meynaud and Sidjanski 1965: 25)

In Rabier and Meynaud's approach, the Eurosphere is defined as the communicative public space of those individuals and groups who participate in European integration processes actively, who are directly affected by the consequences of European integration, and who affect the European integration processes by expressing solidarity with 'the European'. To be more precise, in addition to affected elites and citizens these categories include the European Union's political, bureaucratic and technocratic elites. In this form, Rabier and Meynaud's definition of the Eurosphere primarily corresponds to the features of one of the public spaces that we study in this book, that is, the vertical, top-down, trans-European communicative space of pro-EU elites and citizens. Thus, throughout this chapter the Eurosphere does not relate to the European Union's zone of influence, but to the European public sphere. It was invented and initiated by the European Union's founder generation in order to be used as a launch pad in the construction of a comprehensive European public sphere.

At this juncture, it is in order to preliminarily delineate what a European public sphere is and its relationship to the Eurosphere. The European public sphere is more encompassing than the Eurosphere. The Eurosphere is one of the multiple types of public spaces within the 
European public sphere. It entails simply one public: the transnational public of pro-EU elites and citizens. The European public sphere, on the other hand, contains multiple subnational, national and transnational public spaces and multiple publics that are in alliance, contestation and conflict with each other. Among these the Eurosphere is special because it constitutes the European public sphere by connecting the multiple public spaces and publics of Europe to each other through extension of collaboration, contestation and conflict to the European scale. As this volume empirically shows, the Eurosphere (and the European elites who are operating within it) generates positive and negative reactions to itself at all levels of European society, which brings about common political cleavages at the European scale with respect to which individual citizens, social groups and collective political actors take stances and engage in Europe-wide public debates. In this sense the Eurosphere has a causal status in the processes leading to the formation of a European public sphere.

\subsection{A Brief History of the Making of the Eurosphere}

Although the term 'Eurosphere' was not introduced into the literature before 1965, the history of the European public sphere is at least as old as the European Union itself. To some, it is even older than the European Union's history (Kaelble 2002). The idea of a transnational public sphere transcending the boundaries of the EU member states is, on the one hand, one of the main building blocks of the European integration project. On the other hand, it is an umbrella concept that links different EU integration objectives and policies under a common conceptual frame. Important examples of such objectives and policies that form a coherent, integral whole under the concept of the European public sphere are European citizenship, European identity, European demos, European solidarity, European territory, European networks, European communication strategy, European civil society, the four freedoms and European institutions.

If we accept that the main ingredients of a political public sphere are the state (including all its political institutions), civil society, individual citizens, the means and channels of political communication between them and the content of public communication, it would not be incorrect to assert that the formation of the Eurosphere started in the early 1950s with the arrival on to the scene of European history of the Europeanist political elites who were involved in the establishment and running of the European Coal and Steel Community (ECSC). More concretely, through the ECSC they initiated a supranationalization process, that is, the 
creation and strengthening of transnational decision-making bodies that are relatively independent of national states, by instituting a High Authority (today's European Commission), a Common Assembly of national parliamentarians (today's European Parliament), a Special Council of national government ministers (today's Council of the European Union) and a Court of Justice (today's European Court of Justice).

In spite of the fact that the ECSC introduced the world's very first international institutions which were based on the principle of supranationalism, the surrounding international environment was still a world of sovereign nation states weary of war. Mainstream international relations paradigms at that time regarded national governments as the sole legitimate representatives of citizens. Still under the influence of the legacy of strong charismatic political leaderships that were necessitated by the conditions of the last two world wars, international politics was seen as an exclusive task for the elite layer of governments. At such a time, when citizens' and civil society's involvement even in their own countries' international politics and international relations was quite a remote idea, the ECSC introduced indirect citizen involvement, or representation, in supranational decision-making through the Common Assembly. The Common Assembly was composed of nationally elected parliamentarians who were appointed to represent their voters in the Common Assembly in dual mandate. Despite operating basically in consultative capacity until 1979, the Common Assembly was the beginning of a radical break with the government elites' monopoly on transnational decision-making by including nationally elected parliamentarians, from parties in government and opposition alike, in a transnational assembly.

Also, with the establishment of the High Authority and the Court of Justice in addition to the Common Assembly, the ECSC planted the first seeds of a transnational political system and its checks-and-balances scheme. Under the subsequent arrangements of the European Community and the European Union, the European Commission and the European Court of Justice retained and further strengthened their supranational features. Since the 1990s, the Council of Ministers has been gradually transforming from an intergovernmental to a supranational institution with a steady increase in the number of policy areas being decided through qualified majority voting. As research on voting behaviour in the European Parliament shows, European parliamentarians are acting with an increasingly transnational mindset, voting in line with the ideology and preferences of their European party groups rather than on the basis of national interests (cf. Sata, this volume, Chapter 8). While key political 
institutions of the European Union are becoming gradually more supranational, citizens' influence on transnational policymaking has been progressively, yet far from sufficiently, increasing as the European Parliament is empowered vis-à-vis the Council and the Commission in the decision-making procedures.

Within the conceptual frame of the notion of the public sphere, two important advances in the formation of the Eurosphere were the direct links established between individual citizens and the legislature and the judiciary of the European Union. The former link happened through the introduction of direct elections to the European Parliament in 1979. The latter was realized with the Lisbon Treaty, which came into force at the end of 2009, making it easier for individual citizens to bring an action before the General Court of the Court of Justice of the European Union (CJEU) against EU decisions which affect them directly.

However, the linking of the European Commission, the executive organ of the European Union, with individual citizens followed a less direct path. Harrison and Pukallus (2015) claim historians of European integration writing about the European Community (EC)'s communication with citizens are operating with mistaken frames of understanding when stating that the early leaders of the ECSC and EC were not interested in communicating with citizens. It is believed that they wanted less citizen involvement for the sake of efficiency in European integration work. Based on original archive data, Harrison and Pukallus (2015) convincingly document the opposite was the case in a thorough historical study of EU leaders' ways of communicating with citizens and the EU's public communication policies and strategies between 1951 and 1967.

That is, the ECSC (1951-1957), EEC (1957-1992), EC (1993-2009) and EU (1993 onwards) have been conscious of the necessity of introducing measures to communicate with the citizens. Communication measures that started in the 1950s were a one-way conduit from the Information Service of the High Authority (which was named the Press and Information Service in 1955) in order to inform the citizens directly about the ECSC and its decisions, policies and activities through all available means, including mass media. Jacques-René Rabier was the person who founded this institution (Baisnee 2007). Whereas one of the two divisions of this institution gave information services to the trade unions sector, the other division aimed to inform the European public "in its widest extension"" (Harrison and Pukallus 2015: 242).

However, a 1962 Gallup poll showed that, despite the ECSC's efforts, citizens' knowledge of European affairs was extremely low. Recognizing the difficulty of reaching the public directly with limited resources, the ECSC decided to transmit their messages to citizens through influential 
public figures. This was a critical juncture, leading the European leaders from a 'popularist approach' (1951-1962) to an 'elitist opinion leader approach' (1963-1967) in their efforts to construct a European public sphere (Harrison and Pukallus 2015). This was also the beginning of the formation of the Eurosphere, the communicative space of European elites and citizens, which became the driver of the formation of the larger European public sphere. An 'opinion leader approach' meant reaching the public through public figures who were influential in different sectors. The Commission gathered leaders from a wide range of sectors, including civil society, research and education, media, politics, businesses and trade unions. The selected leaders were invited to different activities in order to be socialized as intermediaries between the EEC and the public. These public figures were supposed to constitute the backbone of what Rabier and Meynaud called the 'Eurosphere'.

In contrast to what most research on European integration claims, there was a strong and sincere 'civil aim' in the European leaders' communication efforts (Harrison and Pukallus 2015). The concern was certainly to increase the legitimacy of European political institutions by gaining public recognition for their political performance. However, although top-down communication from supranational institutions to citizens through opinion leaders was thought to improve the supranational institutions' visibility and transparency, this was hardly enough to allow us to call what was being instituted a public sphere, for the High Authority's public communication was mainly a one-way conduit, and citizens' voice and influence were missing in the ongoing elite deliberation and communication. It was once again Jacques-René Rabier who set out to institute Eurobarometer in 1973 in order not only to incorporate citizen input, that is, public opinion, as a source of supranational decision-making, but also to spark the construction of a European public by exposing the different nations' features, opinions and attitudes to each other (Baisnee 2007).

This approach, which incorporates public opinion measurements with top-down message transmission through intermediary transnational elites, forms the basis of today's more advanced European Union strategies to connect with citizens. Both components became more advanced over the years, turning into more comprehensive policies seeking legitimacy for the European Union as a political system. By initiating and sponsoring pan-European networks of civil society organizations, including European federations of political parties and European networks of NGOs, the transnational elite layer in the Eurosphere was widened even more and specialized in different sectors. These attempts were based on the stipulations of the European Union's policy initiatives on communication 
strategy, governance and democracy and dialogue. ${ }^{1}$ The pan-European civil society component comprised both public interest groups and corporate interest groups. This process extended also to efforts to build trans-European networks of higher education and research institutions and think tanks. Some pan-European networks became the European Union's regular dialogue and consultation partners in policymaking processes in their expertise areas, for example, among others, the European Women's Lobby (EWL), the Social Platform of European NGOs (SocialPlatform), the European Network against Racism (ENAR) and the European NGO Confederation for Relief and Development (CONCORD).

The pan-European non-state networks are European-level counterparts of national organizations. A majority of them have headquarters in Brussels. National non-state organizations are members of the panEuropean networks that entrench their legitimacy in both their roots at the national level and the normative power and moral legitimacy of their causes. They claim to perform three functions - voicing a specific public interest toward the European Union, influencing EU policymaking in a special policy area, and increasing their member organizations' awareness about the supranational policies that affect them - though they do not claim to represent the national civil societies (Sicakkan 2012b). In conformity with the notion of the Eurosphere, pan-European networks are supposed to function as intermediaries between national civil societies and the European Union. While they perform these roles, they constitute themselves as the transnational civil society of Europe on a European scale.

To summarize, with the founding of the European Union's political institutions (the European Council, the European Parliament, the European Commission and the European Court of Justice), the first component of the Eurosphere, and of the European public sphere, was established. The Eurosphere, the vertical communicative public space of European and national elites and citizens, can be regarded as established when the European Union's institutions and national civil societies interact with each other regularly and over a long period of time through the pan-European civil society networks. As empirically shown in the chapters of this volume, one observes such regular Europe-wide interactions across national and European levels of civil society.

\subsection{What Was the Purpose of the Architects of the Eurosphere?}

There is no doubt that the Eurosphere was an initiative led by the European Union's founding fathers, who aimed to catalyse the European 
integration processes. Their initial design constituted a one-way, topdown communication style, simply aiming to inform the European public about the European Union. After 1974, Eurobarometer targeted generating mutual knowledge about national public opinions. Although we know that the founding fathers thought the Eurosphere would advance European integration, the depiction given by historians is inconclusive as regards whether they foresaw a causal link between the Eurosphere and the European public sphere. Baisnee (2007) seems, on the other hand, to have captured this in an interview given by Rabier:

The goal was, first, to better know [public] opinion in order to orientate information policy and, secondly, to contribute to revealing European citizens to one another. It was a matter not only of knowing public opinion but also of informing that public opinion about what citizens from other countries thought about common topics. (J.R. Rabier, quoted in Baisnee 2007: 499)

Thus, 'the goal was to create a European public opinion by measuring it and publicizing it ... [T] he Eurobarometer created European public opinion' (Baisnee 2007: 499). What does this actually involve? We need to get help from Habermas to answer this question. Habermas asserts an almost deterministic relationship between the concepts of 'public sphere', 'public opinion' and 'public' when he defines a public sphere as 'a realm of our social life in which something approaching public opinion can be formed' and a public as a 'bearer of public opinion' (Habermas et al. 1974: 49-50). The statements by an architect of the Eurosphere partly indicate that he might be aware of this presumed relationship. In the ideal case of theory corresponding perfectly to facts, this implies that the outcome of creating a European public opinion by measuring and publicizing it was expected to be the making of a European public and a European public sphere in the longer term.

Keeping in mind that Habermas was talking about national public spheres, and not a transnational public sphere of deep, complex diversity, I want to draw attention to the last point made by Rabier about 'common topics'. It is quite frequently argued by scholars and policymakers that a European public sphere does not exist because there are no common European topics in which citizens are interested. Thus, Baisnee (2007) might be right when he argues that research on the European public sphere has been built on the concepts generated by the European Union itself. On the other hand, it might be the case that Rabier imported the idea of 'common topics' from the first generation of public sphere researchers like Habermas. No matter where it originates from, common topics as an indicator of the existence of a public sphere fits better with 
the reality of non-heterogeneous nation states than diverse societies and transnational entities.

\section{CONCEPTUALIZING THE EUROPEAN PUBLIC SPHERE}

Indeed, the elements of the public sphere listed in mainstream theories, that is, a (pan-European) civil society, a (European) citizenry that acts as a public capable of generating a public opinion, a (European) public opinion and a (pan-European) mass media, have been empirically sought by researchers without much success. The conclusion arrived at through such approaches was that a European public sphere does not (and cannot) exist. But is it so that a European public sphere really does not exist? Or is it that our nation-state-oriented concepts were not capable of detecting a transnational public sphere of diversity? As Habermas has repeatedly stated, his conceptual tools on the public sphere were not developed to study postnational entities like the European Union.

In order to understand a transnational public sphere, for example the European public sphere, one needs to take into account its 'composite' (non-homogeneous), 'multi-lingual', 'less institutionalized', 'political centreless' (polycentric) and 'elitist' (multi-level) traits (Kaelble 2002). An adequate indicator of the existence of a transnational public sphere entailing multiple publics and public spaces is rather the existence of European-scale political cleavages. I will turn back to the interview with Rabier in order to make this point more clear. When asked whether a European public opinion existed, Rabier answered:

This is built. European public opinion is the extent to which Europeans think the same way on a number of issues: on democracy, on human rights, on the status of women. This is a general support, tacit, with this distinction, however, that young people and highly educated people are closer to each other in different countries than are other categories of population. This is partly because they are more politicized and read newspapers, etc. The divide is there, in terms of information and training, hence the need for European education. $^{2}$

The above quotation reveals a perception of European public opinion as a singular, aggregative phenomenon. This approach to European public opinion, hence to the European public sphere, was adopted rather uncritically by some politicians and researchers. Consequently, not only in public opinion surveys led by the European Union's political institutions, but also in academic research on the European public sphere, 
similarities rather than European-scale political cleavages were sought across European societies and nations. This concerned similarity in opinions, attitudes, values, discourses and reactions regarding different issues. The search for similarity was doomed to fail even at the point of departure.

Thus, until structuralist media research came on to the scene, the European public sphere was gauged on partly inadequate premises. Media research that offers structural approaches conceptualized the European public sphere in terms of one or more of the following indicators: (1) national media's attention to 'European themes' (e.g. Gerhards 2000; Trenz 2003); (2) the degree of reporting the same events at the same time (e.g. Eder and Kantner 2000); (3) whether news is reported with a 'European framing' or 'similar framing' (Peters et al. 2005); (4) the visibility and resonance of news beyond national borders (Eder and Kantner 2000; Eder and Trenz 2003; Koopmans 2004; Olesen 2005); and (5) the legitimacy of foreign speakers in national public spheres (Risse and Van de Steeg 2003). This line of research has documented that media's attention to Europe-related themes has gradually increased. Media research that deploys 'common/similar discourses' or 'common/similar meaning frames' as an indicator of the European public sphere either reports contradictory findings because the degree of transnational similarity in discourses and meaning frames varies with respect to the 'policy fields one studies' (Koopmans and Erbe 2004, 114) or reports a 'halting' process of Europeanization (Peters et al. 2005).

In addition to deploying national mass media as the empirical equivalent of the concept of the European public sphere while overlooking other options (cf. Baisnee 2007), another, and more serious, predicament of media-focused approaches is their conception of the European public sphere as Europeanization of national public spheres (Eriksen 2005; Koopmans 2007), or as expanding overlaps between national public spheres (Schlesinger 1999), or as a mechanism whose different parts are interconnected in such a way that they respond in a timely way to stimuli received or produced by one part (Eder and Kantner 2000). They presume that national and subnational public spheres will gradually fade away and be replaced by a Europe-wide public sphere through overlaps and/or Europeanization. On the contrary, the political crisis of extremism and populism that the recent financial crisis triggered revealed the strong presence of the national public spheres and national publics after the Eurosphere elites' 60 years of efforts at building a European public sphere. Further, the political crisis of Europe also revealed the interdependent, agonistic coexistence of various public spaces in Europe, for 
example the public spaces of nativists, nation-statists, Europeanists and minorities (cf. Sicakkan forthcoming). Then, what is an agonistic public sphere?

\subsection{The Agonistic Public Sphere}

The agonistic relations between the vertical trans-European public (the Eurosphere) and the other publics of Europe (transnational, national and subnational) are constitutive. On the one hand, they constitute the European public sphere by introducing common, integrative "political cleavages' (Rokkan 1975) on a European scale. On the other hand, they constitute the sub-European public spaces by transforming the publics of Europe in particular directions. On the individual level, multiple and multi-dimensional belongings including the European identity are increasingly spreading. As these three features have increased the complexity of the conflictual relations and become its core characteristics, the European public sphere cannot be properly understood through lenses provided by harmony-seeking consensual, deliberative or aggregative approaches that tend to overlook conflicts and suppress adversarial behaviour and that imply a democratic public sphere cannot develop in conflict-laden diverse societies (cf. Mouffe 1999, 2002, 2007). Therefore, an important task when conceptualizing the European public sphere in agonistic terms is incorporation of the conflict dimension into the concept.

I propose to distinguish between 'the political' and 'politics'. By 'political' I refer to the dimension of antagonism that is inherent in all human society, antagonism that can take many different forms and can emerge in diverse social relations. Politics, on the other hand, refers to the ensemble of practices, discourses and institutions which seek to establish a certain order and to organize human coexistence in conditions which are always potentially conflictual because they are affected by the dimension of 'the political'. (Mouffe 2007: 42)

This distinction does not only explicitly reveal and embrace the conflict dimension in our understanding of politics, democracy and the public sphere; it also points at where to observe agons, that is, adversary contestations, and agonistic relations when doing empirical research: practices, discourses and institutions. Further, in an attempt to domesticate antagonism in public affairs, Mouffe distinguishes between 'enemies' and 'adversaries', and conceptualizes 'them' and 'us' as adversaries, and the relationship between them as agonistic rather than antagonistic: "the aim of democratic politics is to construct the "them" in 
such a way that it is no longer perceived as an enemy to be destroyed, but an "adversary", i.e. somebody whose ideas we combat but whose right to defend those ideas we do not put into question' (Mouffe 2002a: 126). Thus, in an imperfectly truncated form, what constitutes the public sphere is the agons, agonistic relations, conflict structures, adversaries (actors), discourses, and the politics they do. This is the tangible material that the public sphere is made of. In this framework Mouffe does not specify how the constitutive elements of the agonistic plural public sphere are to be assured coexistence against interest-based aggregative or morality-infused deliberative democracy attempts to eradicate or suppress them. Nor do the two other important varieties of the agonistic theory that are developed by James Tully (cf. 2002, 2007, 2008, 2014) and William Connolly (cf. 2002, 2004, 2005, 2010) explicitly and systematically develop this topic beyond the critique that democratic theory has to take account of conflictual relations and accept their eternal existence in politics and society (Mannon 2014). For the purposes of this book, I identify the constitutive elements of the European public sphere in section 3 below. It is important to note that this is an agonistic conceptualization exercise that targets the European public sphere rather than a theory development attempt. However, as the Eurosphere research adopted a grounded theory approach, some of our empirical findings can also be regarded as having some degree of generality beyond the European Union case.

\subsection{Extending the Agonistic Pluralist Notion of the Public Sphere}

In an agonistic pluralist approach the focus is not only on similarity and conformity but also on difference and conflict. In addition, as mentioned, Mouffe points to practices, discourses and institutions as the core elements of an agonistic public sphere. This specification of empirical themes entails two predicaments. First, it derives from an understanding of the public sphere as a single, unified space. Agons and adversary relations can be integrative or divisive. Regardless of this, they are among the constitutive elements of a public sphere. Incommensurabilities may, on the other hand, lead to severe segmentation and fragmentation. If we accept the whole spectrum of conflict as an inevitable part of social relations as agonist theories do, it is reasonable to acknowledge that the public sphere will be at least partly fragmented and segmented. The public sphere does not cease to exist because of fragmentation and segmentation. Second, Mouffe's analytical specification derives from a structuralist approach that places actors, if not agency, in the background. This renders the actors participating in the public sphere anonymous, 
concealing the wide spectrum of different collective actors in the public sphere behind the notion of agency.

Thus, a constitutive agonistic dimension, that is, political cleavages generated by the coexistence of multiple public spaces within one public sphere, cannot be adequately included in the conceptual framework without extending Mouffe's agonistic pluralist approach. Such an extension would be to recognize not only the plurality of individuals, groups and conflicts but also the plurality of public spaces in the public sphere. An agonistic pluralist approach has to search the agons in discourses, institutions, public spaces, collective actors, structures and political cleavages that entail both adversarial and harmonious states of affairs, relationships and interactions.

The extension concerns the multiplicity of publics and public spaces that coexist in a public sphere, which is not necessarily unified in the same way as the public sphere of a relatively homogeneous citizenry. This is about recognizing and accepting the very possibility of a public sphere divided or segmented along various incommensurabilities, but still strongly integrated through a 'modus vivendi' (Gray 2000). In order to incorporate this, my agonistic pluralist approach to the public sphere distinguishes between the notions of 'public space' and 'public sphere', where public space is a constituent element of a public sphere. Observing the historical patterns of new public sphere formations and in contrast to what interest-based aggregative and morality-based rational deliberative approaches imply, I assert that existing public spaces need not fade away or overlap with each other for new ones to emerge, and that a public sphere is constituted by publics and individuals trespassing over the boundaries between multiple historical and new public spaces that coexist.

Such an agonistic public sphere is distinguished from other public spheres by its incorporation of a co-constitutive transcendent public space which is all-inclusive, and a boundary-transgressing public that is in collaboration, conflict and contestation with other co-constitutive publics (e.g. transnational, national, subnational). This includes society-initiated and state-initiated publics and the new spaces of communication, interaction and collective action that they create. The special set of agonistic relations between multiple publics that inhabit the co-constitutive public spaces sharply distinguishes an agonistic public sphere from a notion of the public sphere as a unified and open space of communication. This distinction also incorporates the 'subaltern public spaces' and the element of 'emancipation' into the conceptual frame (cf. Fraser 2007).

The co-constitutive public spaces are distinguished from each other on the basis not primarily of their publics' collective identities but of the 
dominant ideologies and discourses of political order within them (e.g. nationalizing, transnationalizing, globalizing, essentializing, individualizing, genderizing discourses). Agons, that is, contestations, between the publics on determining the common principles on which the political order is to be entrenched are the core theme of the politics between the publics. Discourses of political order are formed and reconstructed by publics within their respective public spaces. They are communicated and negotiated outwards between the public spaces and publics by the boundary-trespassing elites and citizens.

Thus, what constitutes an agonistic public sphere is multiple public spaces, multiple publics, at least one transcendent public space, at least one boundary-trespassing public, boundary-transgressing groups and individuals in all types of public spaces, discourses of political order and political cleavages. It is the agons, platforms, institutions and boundarytrespassing actors that are the integrative forces in an agonistic public sphere. The integrative role of the transcendent public space materializes through different publics' positions and stances, as well as the actions they take for or against the trespassing public and transgressing groups and individuals. That is, it is the politics occurring across and between the public spaces that makes them parts of a public sphere, politics that is made possible by transgression and the trespassing of boundaries. In the context of the agonistic European public sphere, the transcendent public space is the Eurosphere, and the trespassing public is the trans-European public of pro-EU and pro-diversity elites and citizens. It is the agonistic coexistence of the Eurosphere with the historically existing other public spaces that makes a European public sphere possible.

\subsection{The Eurosphere as the Defining Component of the European Public Sphere}

Following the depiction of the extended notion of an agonistic public sphere, the European public sphere should be conceptualized as a sphere that consists of several different types of public spaces that coexist at different levels, where the top-down trans-European public sphere, that is, the Eurosphere, is the defining constituent public space. The same holds true for the conceptualization of a European public: a transEuropean public is the defining public among the multiple types of public that constitute the European public. Note that I am not deploying 'European', 'transnational' and 'trans-European' interchangeably. The condition for imagining this complex set of public spaces and publics as components of the European public sphere is that they constitute a 
unique cleavage system comprising discourses, alliances and polarizations that contest each other.

Thus, from an extended agonistic pluralist perspective, the European public sphere has come into being with the emergence of a transEuropeanizing public space (the Eurosphere) and a trans-European public (Eurosphere elites and citizens and their networks and non-state organizations) that stretch over different levels of the EU political and social systems and that coexist, interact and contest with the other current public space types. The European public sphere is radically different from national public spheres. In contrast to national public spheres, it is level-wise and territorially more polycentric; it is not as intrusive and permeating as the national public sphere is; it does not aim to dominate all publics of Europe; its driving force, that is, the trans-European public in the Eurosphere, largely appears as of equal worth in relation to other publics through a geographical understanding of Europeanness, though in contrast to its own egalitarian discourse it displays elitist exclusiveness and a depoliticizing moral superiority in its practices, networks and institutions.

Exploring the role of the European Union's policies in the puzzle that the Eurosphere has brought about, I have already shown in the beginning that the Eurosphere was intentionally built by the European elites to facilitate the formation of a unified European public sphere. A quick glance at the European Union's and the trans-European networks' webpages will show that the European Union's institutions interact intensively with the pan-European networks and trans-European elites. In this sense, part of the Eurosphere's objective has been achieved.

However, although their connections with the European Union's political institutions are fairly good and in some areas also structured and formalized, the scope of their links with national and local civil societies do not seem to match this (Sicakkan 2012b). The pan-European networks and the elites leading them are trying to justify their role with respect to the moral power of the normative ideals that they are advocating - for example human rights, minority rights, citizen rights, individual rights, gender rights, environmental values, the rule of law, democracy, and so on - rather than as representatives of national civil societies. They do not justify their existence based exclusively on the participation of national civil society organizations in the networks and the support that they get from national civil societies. Despite this, the pan-European civil society networks are working to ensure the participation of national civil society organizations in their networks.

On the other hand, civil society organizations operating at the member state level foresee the danger of pan-European networks of civil society 
becoming merely the messengers of the European Union, conveying values and discourses only downwards and not upwards in the multi-level civil society system that has been created (Sicakkan 2012b). This is a structural conflict between the pan-European networks' headquarters and the non-state organizations that are their members.

Another structural conflict concerns transnationalist, Europeanist nonstate organizations operating at the national level that are categorically against collaboration with pan-European networks. They resist joining or collaborating with the pan-European networks, and some even work against them because they regard these networks and the European Union as undemocratic and not capable of protecting the citizen and human rights earned within the nation state, since they exist as top-down initiatives by the European Union. They are suspicious of the panEuropean networks also because these networks use a technocratic terminology, which affects ways of thinking, and that they transmit messages one way, from the European Union to national civil societies. In addition to these liberal-democratic and left-leaning objections to the trans-European networks that are partly sponsored by the European Union, we find also nationalist, populist and right-wing extremist groups that are organized transnationally against the postnational, permissive and all-inclusive inclinations in the Eurosphere (Sicakkan 2012b).

In other words, the formation of the European public sphere continues and is still advancing. This is so not only because the trans-European elite layer was partly a successful intermediary carrying messages from the supranational institutions to national civil societies, but also because of the widening and transnational networking of grassroots and other types of political actors that are for and against the normative ideals of the European Union. In particular, certain national-level non-state organizations that are critical about the elitism, permissiveness and top-down communication through the Eurosphere formed their own trans-European networks within the European public sphere (Sicakkan 2012b).

\section{THE COMPONENTS OF THE AGONISTIC EUROPEAN PUBLIC SPHERE}

The above examples of structural conflict and contestation were an introductory foretaste exemplifying the agons in the European public sphere. In this section, I identify the publics, public spaces and actors of the European public sphere. What is meant by public spaces? What are their features? Which discourses of political order do they entail? Which publics do they accommodate? Which networks link them outwards? 
Which actors transgress their boundaries? How does the Eurosphere render them constituents of a European public sphere? In the following, I will briefly answer these questions. ${ }^{3}$

\subsection{Publics, Public Spaces and Discourses of Political Order in Europe}

Historically, different types of public spaces have emerged in Europe. In order of their appearance in European history, the major types of public spaces that currently coexist are (1) essentializing ethnic, religious or national spaces, (2) nationalizing public spaces of the modern nation states, (3) trans-Europeanizing public spaces, and (4) globalizing or transnationalizing public spaces, which correspond respectively to ethnic and religious publics, national publics, trans-European publics, and transnational or global publics (cf. Sicakkan 2006). Through European integration, each of these public space types has found its expression and representation at different levels.

Before proceeding, the fluctuations in terminology below such as 'national' and 'nationalizing' or 'trans-European' and 'transEuropeanizing' need some explanation. This concerns the distinction between being, becoming and making. Whereas 'trans-European space' means what a social space is, 'trans-Europeanizing' may connote either what it is making the European public sphere into or what it is becoming itself. Here, I only deploy the distinction between being and making. Thus, a nationalizing public space means a public space whose coexistence in the European public sphere contributes to making the European public sphere a sphere of national public spaces. This distinction applies to the other public space categories in a similar way.

Throughout processes of state formation and nation building, the notion of the public sphere evolved from being the legitimizing aspect of states' sovereignty and political organization to serving as a tool of collective identity promotion and citizen intervention, which led to a conception of the public sphere as a reference and a space of belonging and citizen politics. To the already existing ethnic and religious essentializing spaces, these processes added the national spaces of interaction. National spaces comprise mass political parties, political and economic interest organizations, nationwide media, and elites. However, the national spaces have not necessarily expressed the existing diversities within societies, something which resulted in the survival of the essentializing spaces as well as provoking the emergence of new subnational public spaces. These essentializing public spaces created their own modes of meaning, interaction and participation both within and beyond 
the frames of the nation states. Essentializing spaces are those spaces that accommodate singular forms of ethnic, religious or diasporic belongings; they are organized in ethnic and religious political parties, organizations, and ethnically and religiously oriented media as well as elite and expert forums.

The forms of belonging reaching beyond the boundaries of nation states and beyond essentializing spaces led to the emergence of new public spaces - transnationalizing spaces. Transnational spaces accommodate cross-border political belongings based on common values that challenge the boundaries of national and essentializing spaces. They represent cross-border social political organizations that exclude singular ethnic, religious, national and diasporic modes of belonging. The transnational space is, thus, different from various versions of 'transnational politics' where national references of meaning persist and constitute the basis for political action. Transnational spaces are also different from diasporic spaces that relate to physically de-territorialized singular belongings. They are about people, and their actions and interactions, which are also psychically de-territorialized. The transnational space comprises transnational organizations and associations with non-spatial expressions and de-essentializing symbolisms. This symbolism relates to misalignments between transnational spaces and other types of spaces, including also national and European public spheres. Transnational spaces accommodate people with multiple references of identification. They find their concrete expressions in trans-border organizations and networks as well as corporative organizations that function as channels of communication with national elites and governments and with the EU institutions.

Conceptualized as a gradually growing process of merging of markets and politics within and beyond the boundaries of nation states, globalization has further affected national states' normative, instrumental and symbolic influences on public sphere formation. The concept of glocalization has in our terminology come to mean the processes of mirroring, protrusion, and appearance of the new ethics, symbols, loyalties, and references of meaning created in globalization, beyond the nation state's frames, and in concrete 'places' located within nation state territories. The glocal space is thus the facade of globalization in our concrete localities. The proliferation of alternative references of identification through globalization has added new, alternative belonging modes and citizenship practices to people's lives. These stretch beyond nationality, ethnicity, religion, nation, minorities, majorities, and territorial belongings. The distinguishing characteristic of the new forms of belonging and new practices of citizenship is the mobility of subjects' minds and bodies 
between different references of identification (Sicakkan 2006). Coupled with conventional politics' insufficient capacity to respond to citizens' interests emanating from these new modes of belonging, the consequence of this proliferation to politics is the emergence of glocal spaces. Glocal spaces accommodate essentializing belongings, national modes of belonging, transnational modes of belonging, and belongings inspired and informed by the idea of a diverse society. Glocal spaces entail a variety of local incipient forms of all-inclusive organizations.

To these, we can add the trans-European spaces which are in formation as a consequence of the processes of European integration. TransEuropean spaces are quite similar to glocal spaces in terms of facilitating the diversity and equality of belongings. People with glocal and European belongings see the European Union as a better political entity than the nation state because they believe it gradually eradicates the existing national boundaries in Europe (Sicakkan 2006: 111-114). However, whereas people with European belongings stop reasoning at this point, persons with glocal belongings continue: They perceive the European Union as another political entity that divides humanity with new boundaries, like nation states did. Yet the European Union, for them, is better than nation states because its borders are broader (Sicakkan 2006: 111-114). This adds a new distinction to our analytical categories, namely the distinction between 'the global subject' and 'the euro-subject' accommodated in, respectively, 'glocal spaces' and 'trans-European spaces'.

To summarize, in order of chronological appearance in political history, the first type of public space is that of essentializing spaces. Essentializing spaces are observed in some of the European states' religious and ethnic minorities which view their own and other identities as unalterable and fixed for all time. In Europe, they have formed their own spaces of interaction, meaning, and channels of participation in politics and in the society at large. The dominant discourse of political order in essentializing spaces is entrenched in primordialist assumptions of identity and ethnicity. The second type comprises the nationalizing spaces, which were created by the nation states. The national space entails state-building peoples and minorities that have been assimilated into the national mode of belonging. The discourse of political order derives from a naturalistic idea of the nation state which takes the international system of nation states as granted. Also national public spaces may appear with an essentializing belonging-content, and historically this has happened in states with a high degree of ethnic homogeneity. The third type is the transnationalizing spaces, which exclude essentializing and territorialized forms of belonging. The discourse of political 
order that upholds transnationalizing spaces is entrenched in an assumption of identity, belonging and state that is detached from territory and state. The interactions in transnational spaces are cross-border, organized in transnational organizations, and aimed at bypassing the existing political and territorial boundaries between humans. The fourth type of public space is glocal spaces, where all the above-mentioned modes of belonging and participation forms coexist. The fifth type is the emerging trans-European spaces, which comprise belongings situated in local contexts that are characterized by a high degree of identification with Europe either instead of or in addition to the aforementioned references of identification. Glocal spaces and trans-European spaces constitute an alternative to the traditional notions of public space, and they may be seen as prototypes of the diverse societies of the future. They both are inclusive of essentialized, national, transnational, glocal and European modes of belonging. Glocal spaces are localized in local incipient organizations throughout Europe (Sicakkan 2006), whereas transEuropean spaces are manifested in Europe-oriented political parties, organizations, social movements and incipient organizations.

The reality is that these public spaces coexist, and emerging public spaces do not necessarily replace the currently existing ones. When operationalized in terms of their political order discourses, actors and their networks, the publics and public spaces reach beyond their own boundaries to constitute a cleavage system of discourses and alliances, in competition with each other to dominate the public sphere. It is the identification of such a cleavage system of contesting discourses and alliances at the European level that allows us to assert that, with the emergence of a trans-European public sphere of elites and citizens (the Eurosphere), and its encounters of conflict and contestation with other public spaces and publics, a European public sphere has emerged.

\subsection{Actors and Networks in the Agonistic European Public Sphere}

Pan-European networks - both those that are initiated by the European Union and those that have emerged either independently from the European Union or as a reaction to its attempts to form a political elite-led civil society - are the backbone of the European public sphere keeping the already existing collective actors and their public spaces linked. As mentioned, this is due to the existence of the Eurosphere.

Analytically, the network dimension of the European public sphere can be approached in two ways. The first approach focuses on 'horizontal' (Koopmans and Erbe 2004) networks where social and political actors seek and get involved in transnational collaboration and communication 
without attempting to build a higher hierarchical level that structures their interactions. The second approach emphasizes 'vertical' (Koopmans and Erbe 2004) networks that seek to articulate more structured, and often institutionalized, channels of collaboration and communication, at the European level. The second approach can be further elaborated in terms of bottom-up and top-down networks. Bottom-up networks emerge through social and political actors' own initiatives to build transEuropean networks seeking to structure and/or institutionalize their collaboration at the European level. Top-down networks emerge through elite-led European-level initiatives that attempt to bring different social and political actors together under their umbrella (Sicakkan 2012b).

Each process and mechanism for forming a trans-European network implies a specific preference for a particular model of a European public sphere. Different preferences concerning involvement in horizontal and vertical trans-European structures, on the one hand, and in bottom-up and top-down structures, on the other hand, imply different approaches to diversity, as well as different attributions of ontological priority to the individual, the collectivity (of different types), the subnational, the national and the European. For instance, some actors deliberately rule out participating in vertical structures because they do not want to contribute to a hierarchical European public sphere structure. Therefore, in transEuropean constellations of national-level organizations, we find not only pro-European orientations but also diverging ideas and strategies concerning how the European public sphere should be structured (or not be structured at all), for example a strictly segmented European public sphere along the lines of a Europe of nations, or a European public sphere as an arena that facilitates only limited transnational collaboration on certain issues that cannot be dealt with only at the national level, or a European public sphere of overlapping publics that follows the multilevel governance structure of the EU, or an ideally integrated single European public sphere, and so on.

The network dimension of trans-European political spaces can be measured by deploying rather simple indicators: (1) the operative level of the networks (regional, national, trans-European interactions); (2) the scope of collaborative interaction (collaborative projects or actions, joint projects or actions, attempts to formulate common objectives, efforts to formulate common actions to address common concerns, synchronizing existing project or action plans, mutual information sharing); and (3) membership status in networks (active membership, passive membership, observer status).

The actors interacting with these networks cover the whole spectrum of social and political actors, including individual citizens, political parties, 
non-state organizations such as social movement organizations, corporate and public interest organizations, NGOs, think tanks, print and broadcast media actors and state institutions. They operate within one of the public space types mentioned in the previous section. Some of them operate, in addition, across different public spaces. They may be open to or sceptical of the existence of one or more of the public space types. They may be for or against the European Union, the European public sphere, the nation state, an ideology or any social group. They may be involved more or less in trans-European collaboration and communication and in European-level public debates. By studying these factors, one may elucidate to what extent actors contribute to the formation of a European public sphere. Further, some features of these collective actors may affect citizen involvement in the European public sphere. It is in order to mention some important public sphere players at this point.

Think tanks and their trans-European networks are important players in the European public sphere because they are involved in work with policy analysis and opinion formation and consultation to decisionmakers at different levels. Another important type of public sphere actor is political parties. Political parties include all sorts of political organizations and political alliances that contest for government power in democratic elections. Social movements and non-governmental organizations are also among the central collective actors participating in public debates. They are political organizations with defined political objectives around clear issue orientations which do not run for government power, but attempt to influence the political decision-making processes and their outcomes in other ways. Media organizations are central entities, both as actors participating in the public sphere and as a channel of communication in the public sphere.

Different features of these collective actors are expected to have different impacts on citizens' involvement in political processes. In this respect we can define two types of collective actors: social and political actors that operate within, from, on behalf of and across communicative public spaces. They constitute and are accommodated by the aforementioned types of communicative public spaces; and they are amongst the key determinants of the structuring quality of such public spaces, which in turn impact upon citizens' involvement and participation at different levels. In this respect these collective entities should be treated both as (1) political and social actors that shape the communicative public spaces and (2) components of communicative public spaces that are shaped by these spaces.

Regarding the former, the relevant feature is collective social and political actors' orientations to different communicative public spaces. 
With their positive, negative or neutral orientations towards singular and multiple types of communicative public spaces (essentializing, nationalizing, transnationalizing, trans-Europeanizing) - combined with their potential structuring, guiding and mobilizing capacity - collective social or political actors influence citizens' ability to think and act as 'coothers', that is, the ability to treat oneself as just another other (Sicakkan 2006), and thus citizens' ways and substance of involvement. The structuring and guiding relationships between communicative public spaces and the mentioned types of social and political actors thus gain relevance, though as an indirect (spurious) explanatory factor. Another relevant feature of social and political actors participating in the public sphere is the type of their collective vision of political society and the public sphere. This is operationalized with the following models: a single protected sphere, multiple segmented spheres, a single shared sphere, multi-level overlapping spheres, multi-level differential spheres, and composite civic spheres (cf. Sicakkan 2012a).

Regarding the latter, physical presence of collective actors as organizations or as incipient organizations in these communicative public spaces constitutes the concrete manifestation of these spaces. In other words, with their presence, they make the communicative public spaces real, tangible and physically and locally available to citizens. In this sense, their locales and organized activities become arenas, channels and ways of citizens' participation and involvement. Thus, channels, forms, issues, events and discourses of involvement that these collective actors make available for citizens are imperative in an analysis of the European public sphere and the public spaces that form it.

Social and political actors subsisting and operating within and across different public spaces and their networks create the publics and public spaces of Europe as well as the European public sphere through the political cleavages they generate on different scales, local, national, European and global. The agonistic pluralist perspective of the public sphere requires identification of the actors that create the constitutive political cleavages and agons by transgressing and trespassing over public space boundaries. An agonistic pluralist approach to transnational and global public spheres requires identification of the networks of actors that emerge as a consequence of their transgression and trespassing.

\section{CONCLUSION}

There are few widely recognized facts to help explain the processes of change in today's Europe, but those facts that are established depict a 
remarkable picture. The European territory is owned and politically structured by nations and nation states. The relations between the European states are to a significant extent characterized by an unprecedented degree of supranational and intergovernmental institutionalization through the European Union and other European organizations and treaties. Although these international institutions increasingly shape their lives, citizens continue to play a minuscule role in European-level decision-making. Next, Europe is inhabited by a complex diversity of historical and new publics. These publics, for example minority publics, national publics, transnational publics, European publics, and new publics that are more challenging to categorize, create their distinct, internal discursive and interactive spaces. The institutional and other collective actors emerging from and operating in these spaces, and giving voice for the publics inhabiting these spaces, interact increasingly beyond their own and other boundaries.

Some of these trans-boundary communications and interactions - be they collaborations, conflicts, exchanges or contestations - can be explained by common past, shared cultural heritage, collective identities, geographical proximity, practical suitability, exit and voice possibilities, political opportunity structures, and elite initiatives. This chapter addressed the ingredients of this reality that cannot be explained exclusively by such factors, but also, with the increasing transgression and trespassing of the boundaries of their immediate surroundings, something which allows them to identify with more distant political entities, hard-to-imagine collectivities, and less tangible ideas about their own belongings.

In order to incorporate these insights, this chapter proposed a conceptual and analytical framework for studying the ongoing formation and structuring of the European public sphere. From an extended agonistic pluralism perspective of the public sphere, which pronouncedly recognizes the plurality of publics and public spaces within a public sphere as well as specifying the institutions and different types of actors participating in it, it conceptualized the European public sphere as a web of (1) existing historical and new publics, public spaces and discourses of political order, (2) networks and social and political actors and, most importantly, (3) a transcendent public space (the Eurosphere) of a transgressing public and the new European-scale political cleavages and agons that they generate in interaction with the other publics and public spaces of Europe.

This approach gives a fresh understanding of postnational public spheres in general and the transnational European public sphere in particular. In the current chaotic picture of citizens, organizations, 
communicative public spaces and political institutions that interact, interconnect and interlink with each other, social and political actors are facilitating or inhibiting the emergence of an inclusive European public sphere in different ways. In this chapter, actors' roles in and contributions to the formation of a European public sphere are understood in terms of the interconnectedness of existing public spaces and interlinkages between organizations (collective actors) beyond a variety of borders and boundaries. It is agons generated by actors' transcendence and transgressing of boundaries that create interconnectedness between Europe's communicative public spaces. On the other hand, it is the different degrees of openness or closure of the existing communicative public spaces that facilitate or obstruct such transcendence and transgression.

Thus, the social and political dynamics of the emergence of a European public sphere must be sought in the tension between the architects, gatekeepers, transgressors and transcenders of borders and boundaries within the existing and newly emerging European publics. Through compliance, endorsement, resistance and opposition, and through boundary-making, gatekeeping, transgression and transcendence, they create multiple poles and polarizations in the very same European political space. This makes them all architects of the European public sphere.

\section{NOTES}

1. White Paper on a European Communication Policy (COM(2006) 35 Final), European Governance: A White Paper (COM(2001) 428 Final) and Plan D for Democracy, Dialogue and Debate (COM (2005) 494 Final).

2. See ec.europa.eu/public_opinion/docs/entretien_rabier.pdf.

3. For a more elaborate discussion of these questions see Sicakkan (2006).

\section{REFERENCES}

Baisnee, O. (2007) The European Public Sphere Does Not Exist (At Least It's Worth Wondering ...), European Journal of Communication 22(4): 493-503.

Connolly, W.E. (2002 [1991]) Identity/Difference: Democratic Negotiations of Political Paradox, expanded edn, Minneapolis: University of Minnesota Press.

Connolly, W.E. (2004 [1995]) The Ethos of Pluralization, Minneapolis: University of Minnesota Press.

Connolly, W.E. (2005) Pluralism, Durham, NC: Duke University Press.

Connolly, W.E. (2010) A World of Becoming, in Alan Finlayson (ed.), Democracy and Pluralism: The Political Thought of William E. Connolly, pp. 222-235, London: Routledge. 
Eder, K. and C. Kantner (2000) Transnationale Resonanzstrukturen in Europa: Eine Kritik der Rede vom Öffentlichkeitsdefizit, in M. Bach (ed.), Die Europäisierung nationaler Gesellschaften, Sonderheft 40 der Kölner Zeitschrift für Soziologie und Sozialpsychologie, pp. 306-331, Wiesbaden: Westdeutscher Verlag.

Eder, K. and H.-J. Trenz (2003) The Making of a European Public Space: An Inquiry into Relating Supranational Politics and Transnational Spaces of Communication: The Case of Justice and Home Affairs, in B. Kohler-Koch (ed.), Linking EU and National Governance, pp. 111-134, Oxford: Oxford University Press.

Eriksen, E.O. (2005) An Emerging European Public Sphere, European Journal of Social Theory 8(3): 341-363.

Fraser, N. (2007) Transnationalizing the Public Sphere: On the Legitimacy and Efficacy of Public Opinion in a Post-Westphalian World, Theory, Culture and Society 24(4): 7-30.

Gerhards, J. (2000) Europäisierung von Ökonomie und Politik und die Trägheit der Entstehung einer europäischen Öffentlichkeit, in M. Bach (ed.), Die Europäisierung nationaler Gesellschaften, Sonderheft 40 der Kölner Zeitschrift für Soziologie und Sozialpsychologie, pp. 277-305, Wiesbaden: Westdeutscher Verlag.

Gray, J. (2000) Two Faces of Liberalism, Cambridge: Polity Press.

Habermas, J., S. Lennox and F. Lennox (1974) The Public Sphere: An Encyclopedia Article (1964), New German Critique 3: 49-55.

Harrison, J. and S. Pukallus (2015) The European Community's Public Communication Policy 1951-1967, Contemporary European History 24(2): 233-251.

Kaelble, H. (2002) The Historical Rise of a European Public Sphere? Journal of European Integration History 8(2): 9-22.

Koopmans, R. (2004) Movements and Media: Selection Processes and Evolutionary Dynamics in the Public Sphere, Theory and Society 33(3-4): 367-391.

Koopmans, R. (2007) Who Inhabits the European Public Sphere? Winners and Losers, Supporters and Opponents in Europeanised Political Debate, European Journal of Political Research 46(2): 183-210.

Koopmans, R. and J. Erbe (2004) Towards a European Public Sphere? Innovation: The European Journal of Social Science Research 17(2): 97-118.

Leonard, M. (2005) Why Europe Will Run the 21st Century, London: Fourth Estate.

Mannon, W. (2014) Applying Principles of Agonistic Politics to Institutional Design, Paper proposed to ECPR Conference, http://ecpr.eu/Filestore/ PaperProposal/6a607c02-3a40-493d-abbc-a0c0bd587551.pdf (accessed 16 March 2016).

Meynaud, J. and D. Sidjanski (1965) Science politique et intégration européenne, Genève: Institut d'études européennes.

Mouffe, C. (1999) Deliberative Democracy or Agonistic Pluralism, Social Research 66(3): 745-758.

Mouffe, C. (2002) Which Public Sphere for a Democratic Society? Intellectuals, Justice and Democracy, Theoria: A Journal of Social and Political Theory 99: 55-65. 
Mouffe, C. (2002a) For an Agonistic Public Sphere, in O. Enwezor (ed.), Democracy Unrealized: Documenta 11, Platform 1, pp. 87-97, Berlin: Hatje Cantz.

Mouffe, C. (2007) Democracy as Agonistic Pluralism, in Elizabeth Deeds Ermarth (ed.), Rewriting Democracy: Cultural Politics in Postmodernity, pp. 36-45, Aldershot: Ashgate.

Olesen, T. (2005) Transnational Publics: New Spaces of Social Movement Activism and the Problem of Global Long-sightedness, Current Sociology 53(3): 419-440.

Peters, B., S. Sifft, A. Wimmel, M. Brüggemann and K. Kleinen-von Königslöw (2005) National and Transnational Public Spheres: The Case of the EU, European Review 3(1): 139-160.

Risse, T. and M. Van de Steeg (2003) An Emerging European Public Sphere? Empirical Evidence and Theoretical Clarifications, Paper presented to the conference Europeanization of Public Spheres, Political Mobilization, Public Communication and the European Union, Science Center Berlin, 20-22 June.

Rokkan, S. (1975) Dimensions of State Formation and Nation-building: A Possible Paradigm for Research on Variations within Europe, in C. Tilly (ed.), The Formation of National States in Western Europe, pp. 562-600, Princeton, NJ: Princeton University Press.

Schlesinger, P. (1999) Changing Spaces of Political Communication: The Case of the European Union, Political Communication 16(3): 263-279.

Sicakkan, H.G. (2006) Glocal Spaces as Prototypes of a Future Diverse Society: An Exploratory Study in Six European Countries, in H.G. Sicakkan and Y. Lithman (eds), What Happens When a Society Is Diverse? pp. 105-148, New York: Edwin Mellen Press.

Sicakkan, H.G. (2012a) Diversity, Polity and the European Public Sphere, Javnost - The Public 19(1): 5-18.

Sicakkan, H.G. (2012b) Trans-Europeanizing Public Spaces in Europe, Javnost The Public 19(1): 103-124.

Sicakkan, H.G. (forthcoming) Is the European Public Sphere Good for Democracy? in Y. Peters and M. Tatham (eds), Democratic Transformations in Europe 31: Challenges and Opportunities, Abingdon: Routledge.

Trenz, H.-J. (2003) Media Coverage on European Governance: Testing the Performance of National Newspapers, EUSA Biennial International Conference, Nashville, TN, 27-29 March.

Tully, J. (2002) The Unfreedom of the Moderns in Comparison to Their Ideals of Constitutional Democracy, Modern Law Review, 65(2): 204-228.

Tully, J. (2007 [1995]) Strange Multiplicity: Constitutionalism in an Age of Diversity, Cambridge: Cambridge University Press.

Tully, J. (2008) Public Philosophy in a New Key, Vol. I: Democracy and Civic Freedom, Cambridge: Cambridge University Press.

Tully, J. (2014) On Global Citizenship, in J. Tully, On Global Citizenship: James Tully in Dialogue, pp. 1-100, London: Bloomsbury. 